\title{
Mandibular temporary immobilization after closed reduction of TMJ luxation with use of surgical mask: technical note
}

\author{
Imobilização temporária mandibular após redução fechada de luxação de \\ ATM com uso de máscara cirúrgica: nota técnica \\ Inmovilización temporal mandibular después de una reducción cerrada \\ de luxación de ATM con uso de máscara quirúrgica: nota técnica \\ Elio Hitoshi Shinohara ${ }^{1}$ \\ Plínio Jun Iti Yokoyama² \\ Fernando Kendi Horikawa ${ }^{3}$ \\ Celso Augusto Lemos Júnior ${ }^{4}$ \\ Iron Ricardo Machado Snidei ${ }^{5}$
} ${ }^{2}$ DDS.Trainee in OMFS. The Square Radiologia Odontológica. Cotia, Brazil

${ }^{3}$ DDS, PhD. Assistant Surgeon. Oral and Maxillofacial Surgery Department. Hospital Regional de Osasco SUS/SP

${ }^{4}$ DDS, PhD. Associate professor. School of Dentistry, Universidade de São Paulo-FOUSP, São Paulo, Brazil

${ }^{5}$ DDS, MD. Head. Oral and Maxillofacial Surgery Department. Hospital Regional de Osasco SUS/SP. Osasco, Brazil

\begin{abstract}
The acute dislocation of the temporomandibular joint (TMJ) is usually reduced using the Hippocratic method/Nelaton maneuver. It is recommended the temporary immobilization of TMJ for pain relief and remission of the inflammatory process that affects the ligaments and articular capsule. This containment is traditionally made with cotton bands but difficult to find if this type of material in a dental office. We present a simple method of mandibular immobilization using disposable surgical mask. We believe it's as effective as the traditional bandage, easily and quickly applied, cheaper and made with material that is readily available in dental offices. We are using this device for more than 15 years with excellent results and we recommend the use.

Descriptors: Temporomandibular Joint; Fracture Fixation; Immobilization.
\end{abstract}

\section{Resumo}

A luxação aguda da articulação temporomandibular (ATM) geralmente é reduzida usando o método de Hipócrates / manobra de Nelaton. Recomenda-se a imobilização temporária da ATM para o alívio da dor e para a remissão do processo inflamatório que afeta os ligamentos e a cápsula articular. Esta contenção é tradicionalmente feita com bandas de algodão, mas é difícil de encontrar se este tipo de material em um escritório dental. Apresentamos um método simples de imobilização mandibular com máscara cirúrgica descartável. Acreditamos que é tão eficaz quanto a bandagem tradicional, fácil e rapidamente aplicada, de menor custo e feita com material que está prontamente disponível em consultórios dentários. Estamos usando este dispositivo há mais de 15 anos com excelentes resultados e recomendamos o uso.

Descritores: Articulação Temporomandibular; Fixação de Fratura; Imobilização.

\section{Resumen}

La dislocación aguda de la articulación temporomandibular (ATM) generalmente se reduce con el método Hipocrático / maniobra de Nelaton. Se recomienda la inmovilización temporal de la ATM para el alivio del dolor y para la remisión del proceso inflamatorio que afecta los ligamentos y la cápsula articular. Esta contención se hace tradicionalmente con bandas de algodón, pero es difícil de encontrar este tipo de material en un consultorio dental. Presentamos un método simple de inmovilización mandibular con máscara quirúrgica desechable. Creemos que es tan eficaz como el vendaje tradicional, fácil y rápidamente aplicado, de menor costo y hecho con material que está fácilmente disponible en consultorios dentales. Estamos utilizando este dispositivo desde hace más de 15 años con excelentes resultados y recomendamos el uso.

Descriptores: Articulación Temporomandibular; Fijación de Fractura; Inmovilización.

\section{INTRODUCTION}

The acute dislocation of the Temporomandibular Joint is generally reduced by manual manipulation using Nelaton or Hipocratic method ${ }^{1,2}$ (Figure 1).

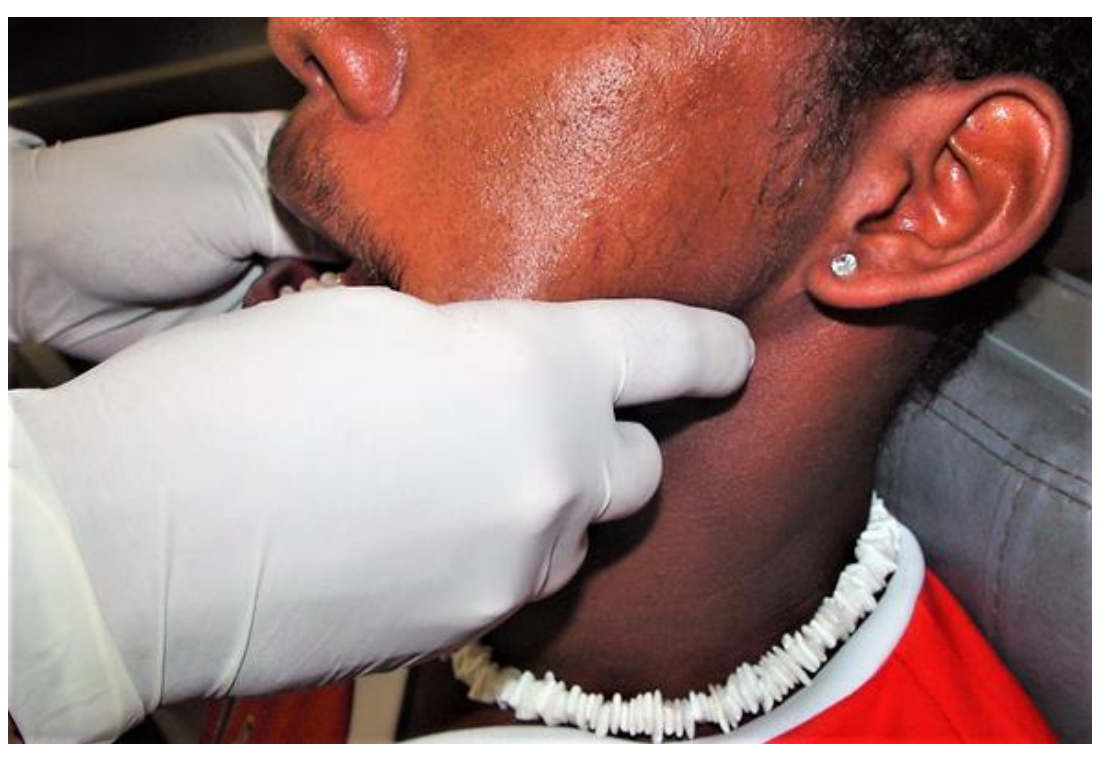

Figure 1: Nelaton's maneuver. We don't use any kind of finger protection and we never saw the legendary occlusal whiplash reflex.
After reduction, mandibular immobilization is indicated to restring movement and ease articular pain at least for 24 hours and ice bags and analgesics are recommended. It is believed that restringing mandibular movement prevents another dislocation and diminish masticatory load on injured ligaments of the temporomandibular joint. Mandibular retention is done using orthopedic cotton bandage or other tissue available in emergency departments of hospitals, but when this patient is referred to the dental office, the general practitioner rarely has such material.

\section{TECHNICAL NOTE}

We present a simple method of mandibular immobilization using disposable surgical mask. We believe it's as effective as the traditional bandage, easily and quickly applied, cheaper and made with material that is readily available in dental offices (Figure 2). We are using this device for more than 15 years with excellent results and we recommend the use. 


\section{CONFLICTS OF INTERESTS}

The authors declare no conflicts of interests.

\section{CORRESPONDING AUTHOR}

Elio Hitoshi Shinohara

elioshinohara@yahoo.com.br

Received 10/01/2018

Accepted 10/02/2018
Figure 2: The surgical mask in position. We use two superposed mask for more stability.

\section{REFERENCES}

1. Bouso OV, González GF, Mommsen J, Grau VG, Fernández JR, Micas MM. Neurogenic temporomandibular joint dislocation treated with botulinum toxin: report of 4 cases. Oral Surg Oral Med Oral Pathol Oral Radiol Endod. 2010; 109(3):e33-7.

2. Quessard A, Barriere P, Dupeyron P. Luxation de l'articulation temporo-mandibulaire diagnostiquée au décours d'une anesthésie générale. Ann Fr Anesth Reanim. 2008; 27(10):846-9. 